\title{
Habitat-associated intraspecific variation in behavior and stress responses in a demersal coral reef fish
}

\author{
Meagan N. Schrandt ${ }^{1,2, *}$, Sean C. Lema ${ }^{1,3}$ \\ ${ }^{1}$ Department of Biology and Marine Biology and Center for Marine Science, University of North Carolina Wilmington, \\ Wilmington, North Carolina 28403, USA \\ ${ }^{2}$ Present address: Department of Marine Sciences, University of Alabama and Dauphin Island Sea Lab, Dauphin Island, \\ Alabama 36528, USA \\ ${ }^{3}$ Present address: Department of Biological Sciences, Center for Coastal Marine Science, \\ California Polytechnic State University, San Luis Obispo, California 93407, USA
}

\begin{abstract}
Habitat heterogeneity has been linked to species diversity and abundance, but can also generate intraspecific behavioral variation that has functional consequences for how animals respond to environmental stressors. Previously, we found that bicolor damselfish Stegastes partitus inhabiting the fringing coral reefs of Curaçao exhibited intraspecific variation in agonistic behaviors in spatial patterns associated with the reef's transition from live coral colonies to rubble. Here we demonstrate for the first time that these fish also vary in physiological stress reactivity with habitat type. Bicolor damselfish collected from live coral and rubble habitats were sampled either $<2.5 \mathrm{~min}$ (baseline) or $20 \mathrm{~min}$ (stressed) after capture to assess stressor-induced responses of cortisol and mRNA abundance for stress-associated endocrine genes (corticotropin-releasing hormone [CRH], urotensin 1 [U-I], CRH-binding protein [CRH-BP], and CRH receptors 1 and 2) in the brain. Acute capture stress increased plasma levels of cortisol in male and female damselfish from both habitat types, but triggered gene transcript responses contingent on the fish's habitat and sex. In males from both habitats, capture stress increased relative transcript abundance for $\mathrm{CRH}$, U-I and CRH-BP. Females, however, exhibited stress-responsive changes in transcript abundance that were habitat-dependent, with capture stress increasing CRH, U-I and CRH-BP mRNA levels in females from live reef, but decreasing levels of these same transcripts in females from rubble. These results provide evidence that intraspecific variation in behavior in bicolor damselfish is linked to variation in physiological stress reactivity in spatial patterns reflective of the local ecological characteristics of the coral reef.
\end{abstract}

KEY WORDS: Fish · Aggression $\cdot$ Cortisol $\cdot$ Coral reef $\cdot$ Habitat change $\cdot$ Corticotropin-releasing factor $\cdot$ Conservation $\cdot$ Stress reactivity

\section{INTRODUCTION}

In marine ecosystems, fish species richness, abundance and diversity are often closely linked to habitat structure. Habitats exhibiting a high degree of spatial complexity or microhabitat variety frequently support a wider diversity - and often greater abundance-of species (Luckhurst \& Luckhurst 1978,
Roberts \& Ormond 1987, Harborne et al. 2008, DeRaedemaecker et al. 2010). What is less commonly recognized, however, is that heterogeneity in habitat conditions can also shape the behavior and physiology of animals in ways that affect how they cope with different ecological demands. In coral reef ecosystems, for example, habitat structure varies considerably across the reef and, accordingly, relates to spa- 
tial variation in the behavior of reef fish (Mumby \& Wabnitz 2002, Kavanagh \& Olney 2006, Schrandt et al. 2011). Similarly, variation in growth rate and reproductive physiological condition in coral reef fishes have also been linked to spatial variation in reef habitat structure (Pankhurst et al. 2008, Feary et al. 2009), indicating that a reef's physical structure can affect not only the behavioral dynamics of demersal fishes, but also the physiology underlying other traits.

Hormones are chemical signaling molecules that link variation in environmental conditions to the phenotypic responses of organisms. Hormones thereby play key functions as mediators of the behavioral, life history and physiological shifts that are crucial for animals to cope successfully with changes in their environments. From studies in terrestrial vertebrates, it has become clear that animals occupying dissimilar habitats can exhibit different hormone profiles as well as distinct hormonal responses to changing environmental conditions. In particular, several studies in terrestrial species have demonstrated that profiles of stress reactivity - or the response of glucocorticoids and other hormones involved in stress response signaling - can vary among populations of the same species occupying ecologically dissimilar habitats (Wasser et al. 1997, Boinski 1999, Müllner et al. 2004, Lucas et al. 2006). Individual variation in stress reactivity has also been linked to stable individual differences in behavior (e.g. temperament or personality) in vertebrates (e.g. Boinski 1999, Cockrem 2007, Silva et al. 2010), suggesting that these geographic patterns of intraspecific variation in stress reactivity that have been observed in the wild may result from the local adaptation of populations to distinct environmental challenges (Boinski 1999, Øverli et al. 2007), or perhaps from the partitioning of animals with different 'personality types' into different habitats either by habitat selection or agonistic behavioral interactions. In either case, population-level differences in stress reactivity in terrestrial species that can be linked to differences in ecological conditions suggests that an individual's ability to be successful in a given environment is dependent on both the challenges presented by its local habitat conditions and that individual's capacity to respond appropriately to those challenges via the physiological stress response. In heterogeneous marine habitats such as coral reefs, it has already been established that habitat heterogeneity can lead some coral reef species, such as fishes, to exhibit intraspecific variation in behavioral and life history traits that are crucial to their population dynamics and functional roles in coral reef communities (e.g. Afonso et al. 2008, Feary et al. 2009, Paddack et al. 2009, Schrandt et al. 2011). Such habitat-associated phenotypic variation is likely to have underpinnings in the physiological stress systems. Identifying that variation in stress physiology is relevant for understanding the proximate mechanisms of how any such trait variation arose, and providing insights into how coral reef species might respond to future changes in their habitat conditions.

Although the physiological and behavioral mechanisms by which teleost fishes respond to environmental stressors have been examined in model species, much less is known about how stress signaling pathways might relate to intraspecific behavioral variation among individuals or populations in the wild (Barton 2002, Pankhurst 2011). In fish, the glucocorticoid stress response occurs via activation of the hypothalamic-pituitary-interrenal (HPI) axis, which is analogous to the mammalian hypothalamic-pituitary-adrenal (HPA) stress axis and is a vertebrate adaptation for coping with a dynamic environment (Wendelaar Bonga 1997, Mommsen et al. 1999). Activation of the HPI axis commences when the fish perceives a stress signal, which then activates neurons in the preoptic area of the hypothalamus to synthesize and secrete hormones including corticotropin releasing hormone (CRH) and Urotensin-1 (U-I) (Yao \& Denver 2007, Bernier et al. 2008). These hormones, which are bound in the brain to carrier proteins such as CRH-binding protein (CRH-BP), bind to $\mathrm{CRH}$ receptors (CRH-R1 and CRH-R2) to induce physiological effects locally within the brain, as well as stimulate the release of other hormones including adrenocorticotropic hormone (ACTH) from the pituitary gland (Metz et al. 2004, Flik et al. 2006). ACTH subsequently stimulates interrenal cells of the teleost head kidney to synthesize and release the glucocorticoid steroid hormone cortisol into blood circulation, where it has several physiological effects including the mobilization of energy reserves, reallocation of energy away from growth and reproduction, temporary inhibition of immune function, and even changes in behavior that help animals cope with the stressor (Wendelaar Bonga 1997, Mommsen et al. 1999).

In fish, cortisol responses to short-term (or acute) stress are generally considered to be adaptive and function to help the animal reestablish physiological homeostasis or respond behaviorally to the environ- 
mental stressor (Ramsay et al. 2006). Stress, however, can become chronic with continuous or repeated activation of glucocorticoid secretion over longer time scales. In such cases, the physiological stress response can become maladaptive and detrimental to growth, reproduction and immune function (Wendelaar Bonga 1997). Although such maladaptive effects are recognized to result from atypical circumstances such as the collection and holding of wild animals in captivity, significant environmental shifts such as the introduction of a novel predator or a change in habitat resources or structure resulting from human activities could also serve as chronic stressors and contribute to negative fitness consequences to animals in the wild (e.g. Busch \& Hayward 2009, Pankhurst 2011).

In the present study, we examined whether bicolor damselfish Stegastes partitus, a demersal coral reef fish found in the Caribbean Sea, from different coral habitats have differing responses of the HPI axis to acute stress. Schrandt et al. (2011) identified distinct patterns of association between intraspecific behavioral variation in bicolor damselfish and variation in the coral reef environment. More specifically, large ( $>4 \mathrm{~cm}$ total length [TL]) bicolor damselfish inhabiting shallow coral rubble areas exhibited higher rates of aggression, shelter use and courtship than bicolor damselfish in areas with higher coral cover nearer the reef slope (Schrandt et al. 2011). Although this previous work revealed distinct relationships between coral reef characteristics and behavior in bicolor damselfish, the physiological bases for this behavioral variation have not been examined. We therefore explored whether differences in the response of the HPI axis to acute stress were present in large bicolor damselfish occupying 2 discrete types of coral reef habitat: (1) dead coral rubble, characterized by a low percentage of live coral cover substrate, and (2) live coral reef, with a comparatively high percent coral cover. Observations of the behavior of bicolor damselfish from each habitat type were first performed to confirm the behavioral differences observed previously (Schrandt et al. 2011). We then collected bicolor damselfish from each habitat type and quantified changes in stressassociated mRNAs in the brain including $\mathrm{CRH}$, U-I, CRH-BP, CRH-R1 and CRH-R2 following acute capture stress. This integrated experimental design allowed us to assess associations among variations in the physical habitat of the coral reef, the behavior of adult bicolor damselfish, and the response of the bicolor damselfish HPI axis to acute stress.

\section{MATERIALS AND METHODS}

\section{Comparison of stress reactivity in bicolor damselfish from different reef habitats}

Habitat and behavioral assessments

From 2 to 7 June 2009, adult bicolor damselfish were observed and collected from 2 distinct coral reef habitats: dead coral rubble (rubble) and live reef dominated by Montastrea sp. (reef) found at Playa Kalki $\left(12^{\circ} 22^{\prime} 32^{\prime \prime} \mathrm{N}, 69^{\circ} 09^{\prime} 30^{\prime \prime} \mathrm{W}\right)$, located on the leeward coast of Curaçao, the Netherlands Antilles, in the southern Caribbean Sea (Fig. 1). Schrandt et al. (2011) identified distinct spatial patterns of intraspecific behavioral variation in bicolor damselfish associated with the occurrence of these 2 coral habitats at Playa Kalki. Transects (20 $\mathrm{m}$ in length and $3 \mathrm{~m}$ apart) were established on this fringing reef parallel to the shoreline, with 2 transects located in the rubble (depth range: 3.0 to $3.9 \mathrm{~m}$ ) and 2 in live coral habitat (depth range: 5.8 to $7.9 \mathrm{~m}$ ). To confirm location in the appropriate habitat types, photographs taken at $1 \mathrm{~m}$ intervals along each of the 4 transects using a Canon Powershot 990 IS camera were analyzed for percent coral cover using Coral Point Count 3.6 (Kohler \& Gill 2006). Coinciding with our previous findings (Schrandt et al. 2011), rubble transects contained an average benthos cover of $<2 \%$ live coral (range among individual $1 \mathrm{~m}$ intervals: 0.0 to $9.9 \%$ live coral cover), and reef transects had a mean percent live coral cover of $>25 \%$ (range: 4.9 to $58.0 \%$ ).

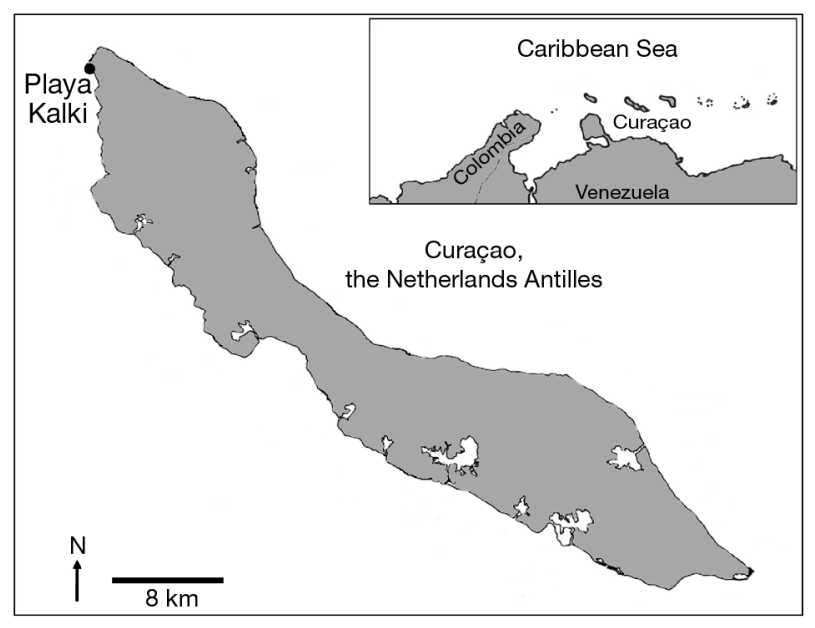

Fig. 1. Location of the Playa Kalki fringing reef sampling site on the leeward side of Curaçao, the Netherlands Antilles, in the southern Caribbean Sea 
The behavior of bicolor damselfish was characterized along each transect by focal observations (conducted between 10:50 and 16:00 h) of individual fish within the 2 habitat types. At $1 \mathrm{~m}$ intervals along each of the 4 transects, a single bicolor damselfish (>4 cm TL) was haphazardly selected and its behavior recorded for $6 \mathrm{~min}$, while the observers remained at least $1 \mathrm{~m}$ away from the focal fish at all times. The frequency of aggressive chases (focal fish either chasing ['by focal' aggression] or being chased by ['at focal' aggression] another fish), shelter use (focal fish entering a shelter) and courtship behaviors (discrete swimming dips performed by males) was recorded (see also behavior descriptions by Myrberg 1972 and Schrandt et al. 2011). A total of 38 and 40 bicolor damselfish were observed from the rubble and reef habitats, respectively. Because male and female bicolor damselfish cannot be reliably sexed in the field based on morphology alone, the frequencies of behaviors were averaged among fish observed within each habitat to obtain general behavioral profiles of bicolor damselfish for each habitat type.

\section{Damselfish collection}

Adult bicolor damselfish ( $>4 \mathrm{~cm}$ TL) were collected (between 12:00 and 16:30 h) with hand nets from the areas between the 2 transects in each habitat, providing a sample of fish from each habitat. For each fish collected, the time at which the fish first entered the net during capture was written on waterproof paper (DuraCopy Waterproof paper, Rite in the Rain). While underwater, divers quickly transferred the captured fish from the hand net to a plastic bag, which was immediately passed to a skin-diver who swam the fish and written time to an additional researcher waiting in a kayak that was anchored at the site and floating at the surface. Once at the surface, collected bicolor damselfish were euthanized (MS-222) at one of 2 times: (1) within 2.5 min of capture for a 'baseline' assessment of stress indices, or (2) at 20 min after capture for a 'stressed' assessment. Fish held until the $20 \mathrm{~min}$ 'stressed' sampling time were maintained in the bag under ambient water temperature until euthanization.

For each fish, blood was collected from the caudal artery and kept cool on ice for up to $2 \mathrm{~h}$ before centrifugation at room temperature for plasma collection. Plasma was stored at $-80^{\circ} \mathrm{C}$. In addition, the brain was dissected immediately after blood collection and stored in RNAlater for subsequent extraction and quantification of stress associated mRNA levels. A total of 52 and 53 fish were collected from the rubble and reef habitats, respectively, with 3-22 fish per sex and sampling time for each habitat. Because male and female bicolor damselfish could not always be readily sexed in the field, gonads were dissected from each fish and fixed for $24 \mathrm{~h}$ in $4 \%$ paraformaldehyde before being stored in $70 \%$ ethanol at $4{ }^{\circ} \mathrm{C}$ for later confirmation of sex by gonadal histology (see the supplement at www.int-res.com/articles/suppl/ m443p153_supp.pdf).

Plasma cortisol measurement

Total plasma cortisol was measured by enzyme immunoassay (EIA) following the methods of Carey \& McCormick (1998) (see the supplement). Plasma samples were run as $2.5 \mu$ volumes in duplicate using polyclonal rabbit anti-cortisol antiserum (1:10 000) and cortisol-horseradish peroxidase conjugate (1:500 000; Fitzgerald Industries International), and were visualized using TMB $\left(3,3{ }^{\prime}, 5,5^{\prime}\right.$-tetramethylbenzidine containing $0.01 \%$ hydrogen peroxide; ThermoScientific) with $1.0 \mathrm{M} \mathrm{H}_{2} \mathrm{SO}_{4}$ as a stop solution.

\section{Quantitative real-time RT-PCR of stress-associated transcripts}

Total RNA was extracted from the whole brains of fish using TRI-Reagent (Molecular Research Center) with bromochloropropane as the phase separation reagent. The resulting RNA was DNase I treated (DNA-free Treatment kit), quantified (Nanodrop 2000, ThermoScientific) and then reverse transcribed (Superscript III reverse transcriptase, Invitrogen). Primers for SYBR green quantitative realtime PCR assays were designed to partial cDNAs for CRH, U-I, CRH-BP, CRH-R1 and CRH-R2 (and elongation factor $1 \alpha$ [EF-1 $\alpha$ ] from bicolor damselfish for comparison as a control gene) that were isolated and sequenced from bicolor damselfish (see the supplement for sequencing details). All primers were synthesized by Integrated DNA Technologies (Coralville, IA, USA) and are provided in Tables S1 $\&$ S2 in the supplement.

All samples were run in $25 \mu$ reactions containing $6.5 \mu \mathrm{l}$ nuclease-free water (Sigma), $12.5 \mu \mathrm{lQ}$ SYBR green Supermix (Bio-Rad), $1.0 \mu$ l each of forward and reverse primers $(3.75-10 \mu \mathrm{M})$, and $4.0 \mu \mathrm{l}$ of reversetranscribed cDNA template under a thermal profile 
of $50^{\circ} \mathrm{C}$ for $2 \mathrm{~min}, 95^{\circ} \mathrm{C}$ for $10 \mathrm{~min}, 42$ cycles of $95^{\circ} \mathrm{C}$ for $15 \mathrm{~s}$ and $59^{\circ} \mathrm{C}$ for $1 \mathrm{~min}$ (MyiQ ${ }^{\mathrm{TM}}$ Single Color PCR Detection System; Bio-Rad). For each gene of interest, a serially diluted standard curve was made from a pool of RNA from samples representing all habitats, times and sexes. All standards were assayed in triplicate. DNA contamination was assessed for each gene measured by analyzing a total RNA sample that was not reverse transcribed, and each qPCR run included 2 samples without cDNA template to further control for contamination. In addition, melt-curve analysis assessed amplification of a single product in each reaction, and specificity of each primer set was confirmed by sequencing selected PCR products. For each gene, correlation coefficients $\left(\mathrm{r}^{2}\right)$ for the standard curve ranged from 0.982 to 0.992 . PCR efficiencies for each gene were calculated using the equation: efficiency $=10^{(-1 / \text { slope })}-1$, and are provided in Table S2 in the supplement. Because EF- $1 \alpha$ transcript abundances were similar between both habitats $(t=-1.835, \mathrm{df}=94, \mathrm{p}=0.0694)$ and baseline and stressed sampling times $(t=1.209$, df $=94, \mathrm{p}=$ $0.2295)$, relative mRNA levels were subsequently normalized to EF-1 $\alpha$ mRNA expression. The expression of each gene of interest was then expressed as a relative level by dividing the resulting values by the baseline stress value of male fish collected from the rubble habitat.

\section{Statistical analyses}

Non-parametric Mann-Whitney $U$-tests were used to examine differences in the frequencies of behaviors of fish from the rubble and reef habitat areas (SPSS 16.0) because data failed to conform to the assumptions of parametric statistics and could not be transformed successfully. Spearman's correlations were also performed to determine whether particular behavioral correlations varied between fish occupying rubble and reef habitats (JMP 7.1 software). All data are shown as means \pm SEM.

Plasma cortisol levels and relative mRNA values were $\log$ transformed to yield normal distributions and analyzed separately for male and female bicolor damselfish using 2-way ANOVA models with habitat origin (rubble or reef) and stress condition (baseline or stressed) as factors. When main factor effects or interaction effects were found to be significant, pairwise comparisons between transcript abundance values for the levels within that factor were calculated using Fisher's protected least significant difference (LSD) tests.

\section{RESULTS \\ Bicolor damselfish behaviors in rubble vs. reef habitats}

The frequency of aggression differed between bicolor damselfish in rubble and reef habitats, with fish in the rubble habitat initiating aggressive interactions (by focal aggression) nearly 4 times more often than fish from reef habitats $(U=294, z=-4.738$, $\mathrm{p}<0.001$; Fig. 2a). Bicolor damselfish from the rubble habitat also showed more frequent aggression overall (total aggression, or the sum of by focal and at focal aggression; $U=219, z=-5.450, \mathrm{p}<0.001$ ) with nearly 3 times more total aggression in the rubble, even though there was no significant difference in damselfish at focal aggression between the rubble and reef habitats $(U=675, z=-0.940, p=0.347$; Fig. 2a). Frequencies of shelter use and courtship also differed between bicolor damselfish in the 2 habitat types, so that fish living in rubble habitats entered shelter more often $(U=547, z=-2.138, \mathrm{p}=$ 0.032; Fig. 2b) and courted females approximately 3 times more frequently $(U=542.5 ; z=-2.484, \mathrm{p}=$ 0.013; Fig. 2c) than damselfish occupying live reef habitats.

The frequencies of some damselfish behaviors were also observed to be correlated, although these correlations were not always similar for fish from rubble and reef habitats. For bicolor damselfish in rubble habitat, courtship frequency was correlated positively with both by focal aggression ( $\rho=0.4682, p=0.0023)$ and total aggression $(\rho=$ $0.5243, p=0.0005)$. These associations between courtship and aggression, however, were not observed in damselfish in the reef habitat $(\rho=$ $0.2500, p=0.1301$ for by focal aggression and $\rho=$ $0.1850, \mathrm{p}=0.2660$ for total aggression vs. courtship). Moreover, although individual variation in the frequency of aggression (any measure) was not related to shelter use for fish in either habitat, shelter use and courtship behaviors were positively correlated in fish occupying reef habitat ( $\rho=$ 0.6506, $\mathrm{p}<0.0001$ ) but not in fish from rubble habitat ( $\rho=0.1243, p=0.4449)$.

\section{Plasma cortisol responses in fish from rubble vs. reef habitats}

In male and female bicolor damselfish, acute capture stress significantly increased plasma cortisol levels, regardless of habitat origin $\left(F_{1,53}=44.1743\right.$, 

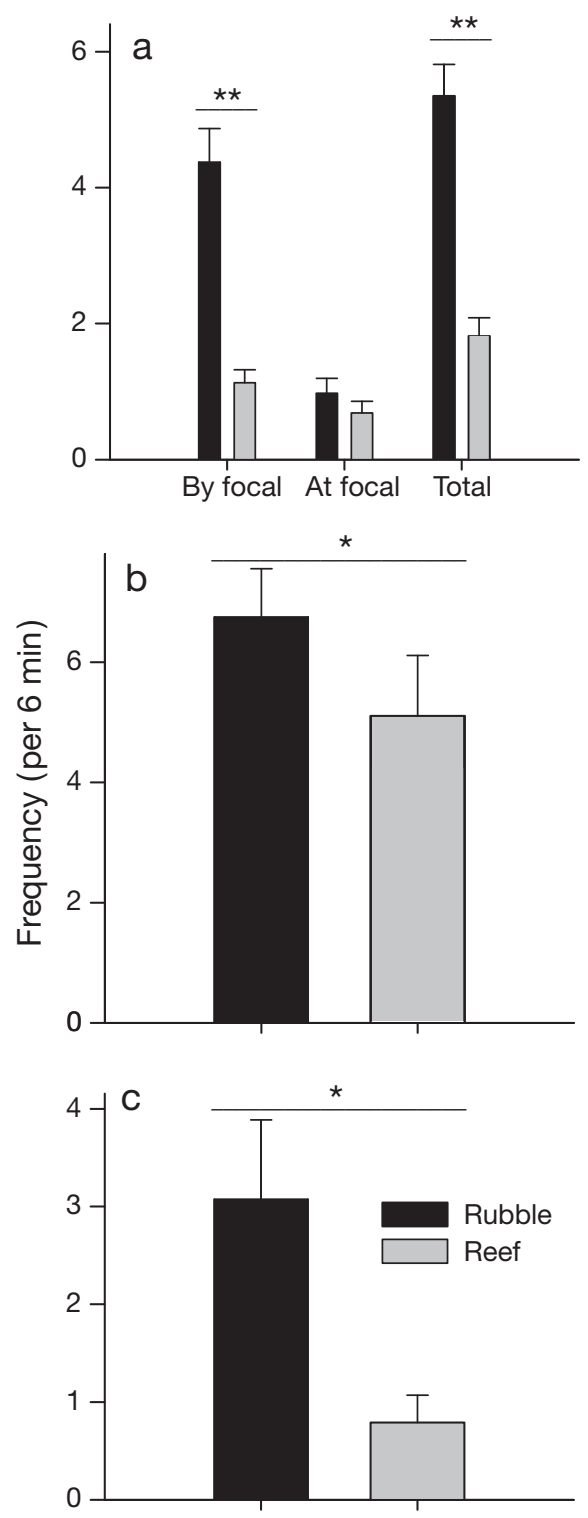

Fig. 2. Stegastes partitus. Behavioral variation in adult bicolor damselfish ( $>4 \mathrm{~cm}$ total length) from rubble and reef habitats. Mann-Whitney $U$-tests revealed (a) more 'by focal' and 'total' aggression, (b) more shelter use and (c) more courtship dips in rubble habitats compared with reef habitats. Asterisks indicate statistically significant differences $\left({ }^{*} \mathrm{p}<0.05,{ }^{* *} \mathrm{p}<0.001\right)$. 'Focal' refers to the fish being observed, so 'by focal' indicates that the focal fish initiated an aggressive interaction with another fish. Data are means \pm SEM

$\mathrm{p}<0.0001$ in males and $F_{1,29}=22.7696, \mathrm{p}<0.0001$ in females; Fig. 3). Baseline cortisol levels were similar between habitats and sexes, and although fish from the reef appeared to have a greater increase in plasma cortisol than fish from the rubble, this trend was not statistically significant (habitat-stress interaction, $F_{1,53}=0.9595, \mathrm{p}=0.3318$ in males and $F_{1,29}=$

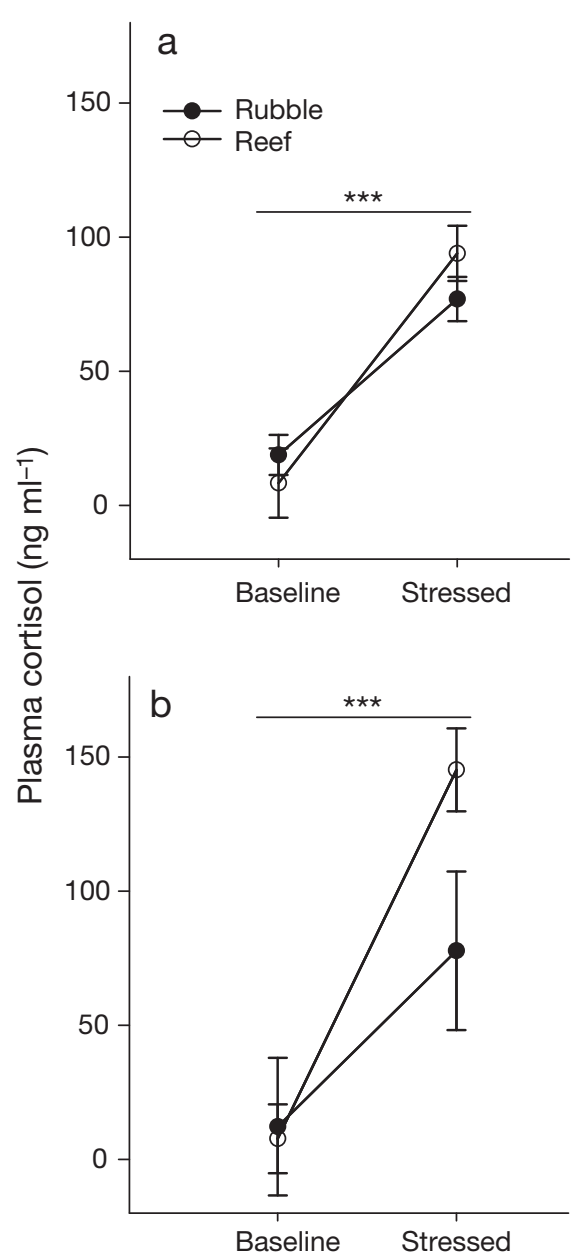

Fig. 3. Stegastes partitus. Comparison of plasma cortisol levels in bicolor damselfish from 2 different habitats and stress levels (baseline: <2.5 min after capture; stressed: 20 min after capture). Two-way ANOVA models with habitat origin and stress condition as factors were used to compare plasma cortisol levels within (a) male and (b) female fish separately. Asterisks indicate statistically significant differences for the stress factor $\left({ }^{* * *} p<0.0001\right)$. Data are means \pm SEM

$2.7634, p=0.1072$ in females) and there was no difference in the cortisol response of fish from different habitats $\left(F_{1,53}=0, \mathrm{p}=0.9999\right.$ for males and $F_{1,29}=$ $2.2670, \mathrm{p}=0.1430$ for females).

\section{Stress-associated mRNA responses in fish from rubble vs. reef habitats}

Acute capture stress increased neural mRNA levels of $\mathrm{CRH}$ in the brain of male damselfish (ANOVA model, $F_{1,36}=5.656, \mathrm{p}=0.0208$; Fig. $4 \mathrm{a}$ ), although pairwise pre- and post-stressed comparisons revealed 
that the magnitude of this change was greater in males from the reef habitat $(t=2.208$, df $=19, \mathrm{p}=$ 0.0397 ) than it was in males from the rubble habitat $(t=1.0908, \mathrm{df}=37, \mathrm{p}=0.2824)$. In female bicolor damselfish, there was a trend for acute stress to affect the relative expression of $\mathrm{CRH}$, with the direction of this change differing between females from the 2 habitats, but this trend was not statistically significant at the $\mathrm{p}=0.05$ level (habitat-stress interaction, $F_{1,33}=3.921, \mathrm{p}=0.0561$; Fig. $4 \mathrm{~b}$ ). In female fish collected from rubble habitats, the relative abundance of CRH transcript was depressed following 20 min of acute stress. Females from the reef habitat, however, showed the opposite response and increased transcript abundance for CRH after acute stress.

Although transcript abundance for U-I did not differ among male damselfish from reef and rubble habitats

Male

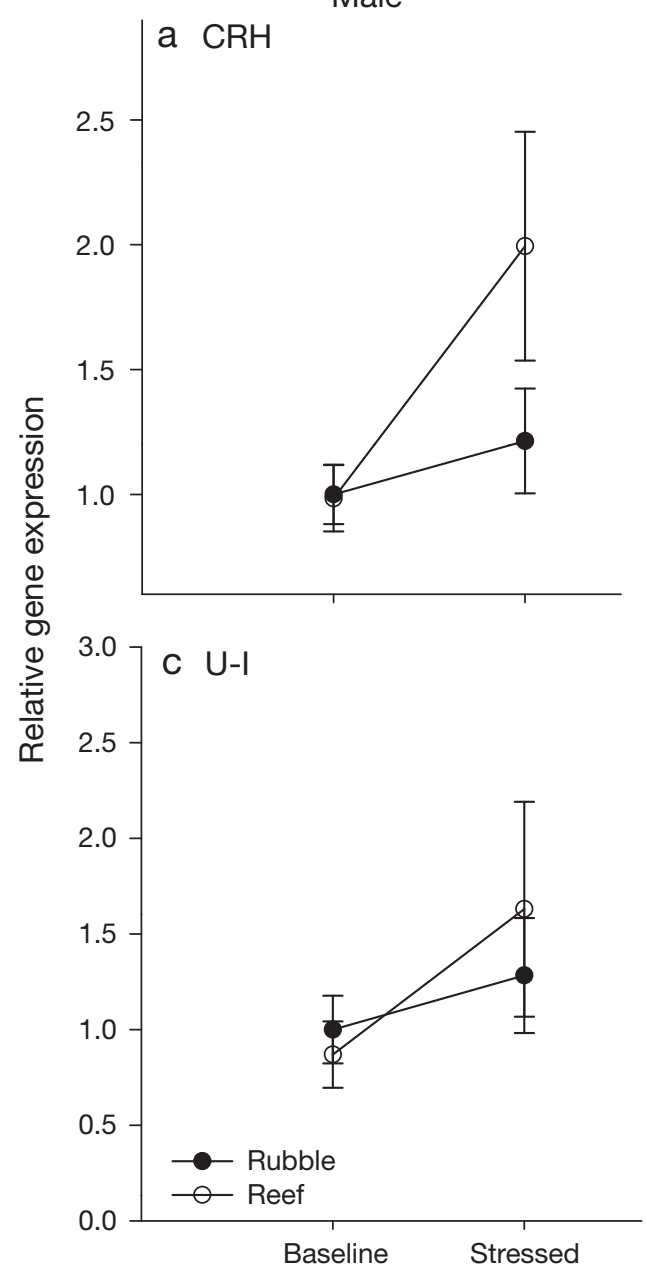

and was unaltered by stress condition (Fig. 4c), U-I mRNA levels were affected by acute stress in females so that relative U-I mRNA levels decreased in the brains of females from rubble habitats 20 min after exposure to capture stress $(t=-2.732, \mathrm{df}=5, \mathrm{p}=0.0412)$, but increased in females collected from the reef habitat $(t=2.122, \mathrm{df}=29, \mathrm{p}=0.0425)$ (Fig. $4 \mathrm{~d})$. The direction of abundance change in U-I mRNAs thereby varied depending on which habitat the fish occupied (habitat-stress interaction, $F_{1,34}=9.883, \mathrm{p}=0.0035$; Fig. 4d), and showed a habitat-specific pattern similar to that observed for $\mathrm{CRH}$ gene transcripts (Fig. 4b) Furthermore, baseline U-I transcript abundance differed between females collected from rubble and reef habitats $(t=3.102, \mathrm{df}=21, \mathrm{p}=0.0054)$.

For CRH-BP, the habitat effect of the 2-way ANOVA was significant only for males, with higher relative

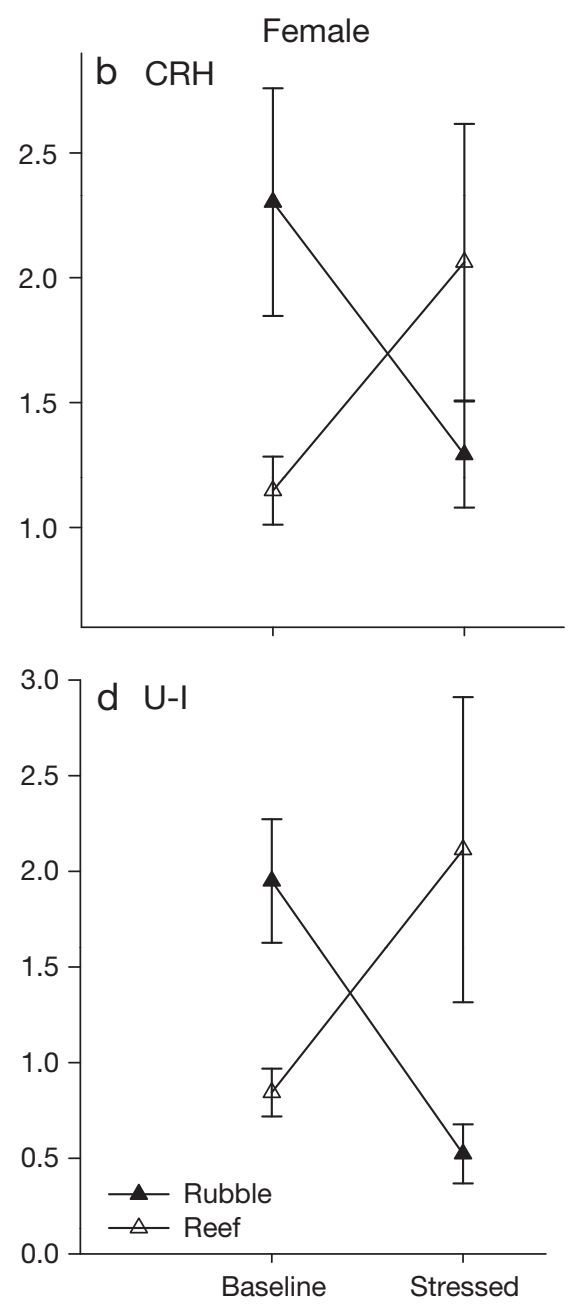

Fig. 4. Stegastes partitus. Real-time quantitative RT-PCR comparison of (a,b) corticotropin-releasing hormone (CRH) and (c,d) urotensin 1 (U-I) mRNA levels (means \pm SEM) in the brain of bicolor damselfish from 2 different habitats and stress levels (baseline: <2.5 min after capture; stressed: 20 min after capture). Two-way ANOVA models with habitat origin and stress condition as factors were used to compare relative mRNA levels within male $(a, c)$ and female $(b, d)$ fish separately. Significant pairwise differences were also found for selected factors identified previously as significant in the ANOVA models (see 'Results') 
mRNA levels observed in male fish from the reef habitat compared with the rubble $\left(F_{1,56}=5.5292, \mathrm{p}=\right.$ 0.0222; Fig. 5a). Relative CRH-BP mRNA levels did not change with capture stress for males collected either from the live reef habitat or from the rubble habitat. In female damselfish, however, we found that relative CRH-BP transcript abundance showed a significant habitat-stress interaction $\left(F_{1,34}=6.300\right.$, $\mathrm{p}=0.0170$; Fig. 5b), indicating that the response of relative CRH-BP mRNA levels to acute stress differed between females collected from rubble and reef areas. Similar to CRH and U-I gene transcripts, the relative abundance of mRNAs encoding CRH-BP decreased following acute stress in females from the rubble habitat, but increased in females from the reef habitat (Fig. 5b).

Unlike transcripts for CRH, U-I and CRH-BP, transcripts encoding CRH-R1 did not vary with habitat or stress condition in either male or female bicolor damselfish (Table 1). CRH-R2 transcript abundance, however, was significantly greater in males from rubble habitats than reef habitats, and increased in abundance in the brains of males from both habitats following 20 min exposure to acute stress (Table 1). CRH-R2 mRNA levels in females were not affected by either habitat origin or stress condition.

\section{DISCUSSION}

Animals in the wild that occupy habitats characterized by dissimilar physical and social environmental

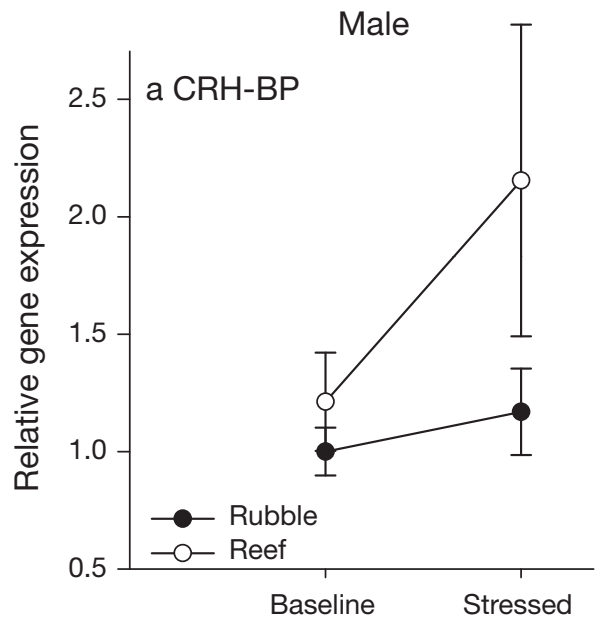

conditions often show differences in behavior, but the physiological bases for such behavioral variation are rarely known. Here, wild bicolor damselfish from 2 coral reef habitats - rubble $(<2 \%$ live coral $)$ and live reef $(>25 \%$ live coral $)$ - were observed to exhibit distinct behavioral profiles and habitatassociated differences in stress physiology that varied with sex. Although bicolor damselfish in both habitats exhibited increases in plasma cortisol levels following exposure to an acute stressor regardless of habitat origin, changes up-axis in the neurohormones (and their affiliated receptors and binding proteins) that ultimately regulate cortisol production and secretion can actually be a better indicator of long-term changes in stress condition (e.g. Denver 2009). For that reason, we looked up-axis at the acute stress-induced responses of neuropeptides regulating the cortisol response to stress, and found that bicolor damselfish from the 2 coral reef habitats differed in how mRNAs encoding $\mathrm{CRH}$ and U-I (as well as CRH-BP, the carrier protein for these hormones) in the brain responded to acute stress. More specifically, we found that relative levels of these transcripts differed between bicolor damselfish from the rubble and reef habitats in sex-associated patterns in both baseline and stressed conditions. This result indicates that intraspecific variation in physiological stress responsiveness in these fish is linked in a sexdependent manner to local variation in environmental conditions on the coral reef. Taken as a whole, these findings provide evidence that coral reef habitat structure has shaped individual variation in stress

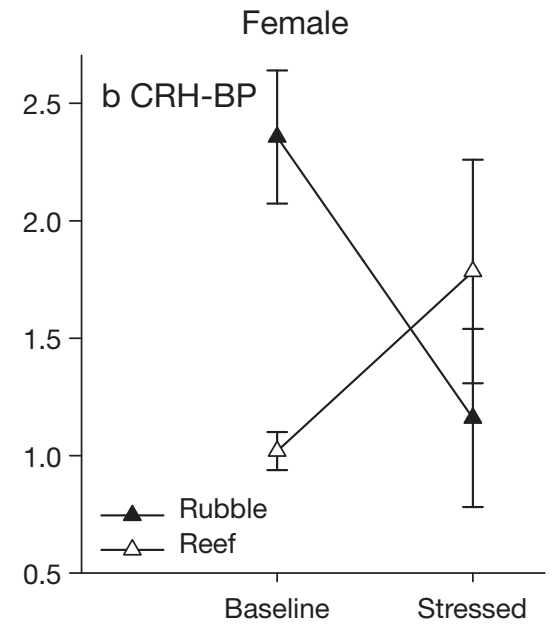

Fig. 5. Stegastes partitus. Real-time quantitative RT-PCR comparison of corticotropin-releasing hormone (CRH)-binding protein (CRH-BP) mRNA levels (means \pm SEM) in the brain of bicolor damselfish. Two-way ANOVA models (see 'Results') were used to test for the effects of habitat origin (rubble or reef) and stress condition (baseline or stressed) on relative mRNA levels within (a) male and (b) female fish. Significant pairwise differences were found for selected factors identified previously as significant in the ANOVA models. In females, transcript abundances of CRH-BP were higher at baseline in the rubble habitat than in the reef habitat $(t=3.858, \mathrm{df}=21, \mathrm{p}=0.0009$ for CRH-BP) 
Table 1. Stegastes partitus. Real-time quantitative RT-PCR comparison of corticotropin-releasing hormone receptor 1 and 2 ( CRH-R1 and CRH-R2, respectively) mRNA levels in the brain of bicolor damselfish from 2 different habitats (reef vs. rubble) and stress conditions (time to euthanasia post-capture: $<2.5 \mathrm{~min}$ vs. $20 \mathrm{~min}$ ). Effects are only shown for statistically significant results at the $\mathrm{p}=0.05$ level

\begin{tabular}{|lccccc|}
\hline Factor & SS & df & $F$ & $\mathrm{p}$ & Effect \\
\hline CRH-R1 male & & & & & \\
$\quad$ Habitat & 0.0110 & 1 & 0.1886 & 0.6658 & - \\
$\quad$ Stress & 0.1558 & 1 & 2.6737 & 0.1077 & - \\
$\quad$ Habitat $\times$ Stress & 0.0001 & 1 & 0.0024 & 0.9608 & - \\
CRH-R1 female & & & & & \\
$\quad$ Habitat & 0.0220 & 1 & 0.3944 & 0.5343 & - \\
$\quad$ Stress & 0.0062 & 1 & 0.1115 & 0.7405 & - \\
$\quad$ Habitat $\times$ Stress & 0.1072 & 1 & 1.9183 & 0.1753 & - \\
CRH-R2 male & & & & & \\
$\quad$ Habitat & 0.3153 & 1 & 6.4112 & $0.0142^{*}$ & $\uparrow$ in rubble \\
$\quad$ Stress & 0.3369 & 1 & 6.8501 & $0.0114^{*}$ & $\uparrow$ w/ stress \\
$\quad$ Habitat $\times$ Stress & 0.0194 & 1 & 0.3954 & 0.5321 & - \\
CRH-R2 female & & & & & - \\
$\quad$ Habitat & 0.0793 & 1 & 1.5111 & 0.2274 & - \\
$\quad$ Stress & 0.0001 & 1 & 0.0024 & 0.9610 & - \\
$\quad$ Habitat $\times$ Stress & 0.0654 & 1 & 1.2451 & 0.2723 & - \\
\hline
\end{tabular}

tor pathways to trigger the production and secretion of ACTH from the pituitary gland, which then stimulates interrenal cortisol secretion (for reviews, see Mommsen et al. 1999, Pankhurst 2011).

In addition to roles for $\mathrm{CRH}$ and U-I in regulating the HPI stress response (Huising et al. 2004, Flik et al. 2006), these neuropeptides also act locally within the brain to cause behavioral and neuromodulatory effects directly. $\mathrm{CRH}$ has been shown to act within the brain to affect locomotor activity (Clements et al. 2002, Lowry \& Moore 2006), and feeding behaviors and appetite (Bernier \& Peter 2001, Bernier \& Craig 2005). Similarly, U-I has been shown to act within the brain to regulate food intake (Bernier \& Peter 2001). Intraspecific variation in brain expression of $\mathrm{CRH}$ and U-I might therefore be indicative of differences

physiology in spatial patterns reflective of the different behavioral (e.g. agonistic interactions, predator encounter frequency) and physiological demands that accompany living in these 2 habitat types.

\section{Causes and functional implications of variation in stress physiology}

In teleost fishes, physiological and behavioral responses to environmental stressors are mediated in part via increases in cortisol secretion from the HPI endocrine axis. Activation of this axis normally begins upon the perception of an environmental stressor (e.g. presence of a predator, interaction with a competitor, change in physical environment caused by a storm event), which triggers the synthesis and secretion of neuropeptides including CRH and U-I from the hypothalamus of the brain (Huising et al. 2004, Flik et al. 2006). In the brain, CRH-BP regulates the biological activity of both CRH and U-I by modulating concentrations of these hormones bioavailable for local effects or release from the hypothalamus (Potter et al. 1991, Seasholtz et al. 2002, Huising et al. 2004). CRH and U-I are closely related structurally (Pittman \& Hollenerg 2009), and recent studies have indicated that U-I activates the CRH-R1 pathway in fish with an affinity similar to that of CRH (Arai et al. 2001, Huising et al. 2004). It is therefore thought that both of these neuropeptides can activate CRH recep- in HPI stress axis regulation or, alternatively, differences in behavioral stress-coping mechanisms.

In the present study, mRNAs encoding CRH, U-I, $\mathrm{CRH}-\mathrm{BP}$ and CRH-R2 differed in relative abundance responses between pre- and post-stressed bicolor damselfish from different habitats of the fringing coral reef. The specific responses following acute stress varied depending on the transcript and sex of the fish. Gene transcripts encoding CRH and U-I in the brain have been shown to increase in relative abundance in captive fishes after acute stress or administration of cortisol (Bernier et al. 1999, Huising et al. 2004), which corresponds to our findings here with male bicolor damselfish. Female bicolor damselfish, however, showed habitat-specific responses of CRH and U-I mRNAs, with elevated relative transcript levels for these genes in females occupying the reef habitats, but reduced transcript levels following tat (Fig. 4b,d). Relative levels of CRH-BP mRNA followed similar sex- and habitat-specific patterns of change with elevations observed in male damselfish from both habitats following capture stress, but opposing patterns of change in female fish depending on their habitat of origin. Previous work has also found increased hypothalamic CRH-BP mRNA levels in fish following acute stress (Huising et al. 2004), although there is evidence that the type of stressor (e.g. hypoxic stress, agonistic social interactions) can affect which brain regions show changes in CRH-BP acute capture stress in females from the rubble habi- 
mRNA levels (Alderman et al. 2008). Nonetheless, the stress-induced changes in CRH-BP relative transcript abundance in both male and female bicolor damselfish followed patterns similar to those seen for CRH and U-I mRNAs in the same sex and habitat origin, which is consistent with CRH-BP's role in regulating bioavailability of these peptide hormones.

But, are there clear links between behavior and the sex differences in stress-induced mRNA responses, or between the environmental conditions in these 2 coral reef habitats and the opposing gene transcript responses in the female damselfish brain? Overall, several lines of evidence suggest that the differential responses of stress-associated transcripts to acute capture stress may relate to variation in male and female social behaviors and, ultimately, the varying ecological demands of the 2 habitat types. Male and female bicolor damselfish are dimorphic in their behavior, with males exhibiting higher rates of aggression as they establish and defend nesting holes in the substratum (e.g. Myrberg 1972). We hypothesize that the differential response of CRH, U-I and CRH-BP relative transcript abundance between male and female damselfish may relate to sex differences in the type and frequency of agonistic social interactions performed and experienced by each sex. In both the present study and previous work with bicolor damselfish at this same reef site in Curaçao, overall frequencies of aggression and courtship were found to be greater in the rubble habitat than in the reef habitat (Fig. 2; Schrandt et al. 2011), suggesting that the magnitude of social stresses in these 2 habitats also likely differ. Schrandt et al. (2011) found that spatial variation in aggression and courtship in bicolor damselfish was strongly linked to the physical structure of the coral reef substrate, with fish behaving most aggressively in rubble habitats characterized by a low rugosity, low coral cover and small substratum holes. The behavioral observations from the present study also revealed positive associations between rates of aggression and courtship for fish in the rubble habitat, but no relationship in the reef habitat. We interpret this habitat-associated difference as an indication that reproductively active males in rubble need to behave more aggressively to defend nesting sites and territories, possibly as a consequence of the higher density of bicolor damselfish in these rubble areas (Schrandt et al. 2011). Similar habitat-specific behavioral profiles have been observed in the closely related beaugregory damselfish Stegastes leucostictus (Snekser et al. 2009). When taken as a whole, these observations suggest that the frequency - and perhaps intensity - of social interactions varies with habitat characteristics. Such habitat-associated spatial variation in male damselfish behavior could lead to different social stresses, and it is possible that the elevated frequency of aggression and courtship by males in rubble areas might even chronically stress females in this habitat.

Further support for this idea can be found in the cortisol response profiles of female damselfish in these 2 habitat types. In general, chronically stressed fish exhibit higher basal cortisol levels as well as shifts in cortisol response profiles when reacting to new stressors (Mommsen et al. 1999; see also Busch \& Hayward 2009 for other vertebrates). However, chronic stress can also impact up-axis hormone production and secretion in ways that ultimately alter patterns of glucocorticoid secretion following perception of a stressor. Cortisol itself regulates brain mRNA levels for up-axis hormones including $\mathrm{CRH}$ and U-I (Bernier et al. 1999, Huising et al. 2004, Alderman et al. 2008), and differences in the timing (rapidity and duration) or relative magnitude of mRNA abundance responses following exposure to an acute stressor may be indicative of an altered HPI axis stemming from chronic or repeated acute stressors. In the particular case here, that means that if females in the rubble habitat were commonly experiencing more frequent or different magnitudes of environmental stressors, one might expect a difference in both the responsiveness of cortisol secretion to an acute stressor and a change in either steadystate or post-stressor production levels of the up-axis hormones that control cortisol secretion. Although the cortisol reactivity profiles of female damselfish in the present study did not differ at the level of statistical significance between habitats, and indeed increased following acute capture stress in females from both rubble and reef areas, females from the rubble did show a trend towards lower cortisol levels in the stressed condition (mean $=78 \mathrm{ng} \mathrm{ml}^{-1}$ ) relative to females from the reef (mean $=145 \mathrm{ng} \mathrm{ml}^{-1}$; Fig. 3). If that difference in cortisol response is biologically relevant, even if not statistically significant at the $\mathrm{p}=0.05$ level, it might help explain the opposing responses of brain CRH, U-I and CRH-BP mRNA levels in females from the 2 habitats. Following that prediction, we found that mRNAs encoding $\mathrm{CRH}$, U-I and CRH-BP had greater relative abundance for females from the rubble habitat in the pre-stressed condition (Figs. 4b,d \& 5b), which supports the hypothesis that females in rubble habitats may experience more frequent or even chronic stressors, perhaps because of the higher male aggression or some other ecological factor. In any case, the differences in 
CRH, U-I and CRH-BP relative mRNA levels were observed in both pre- (baseline) and post-stressed females (Fig. 3), indicating a divergence in HPI-axis responsiveness in these fish from dissimilar coral reef habitats.

It is also important to note that although the primary findings of this study involved the habitat- and sex-specific responses of CRH, U-I and CRH-BP mRNAs to acute stress, we also found that transcript abundance for the CRH-R2 receptor was greater in males from rubble habitat than reef habitat (Table 1). Signals from CRH are transduced across cell membranes via activation of CRH-R1 and CRH-R2 receptors (Grammatopoulos \& Chrousos 2002, Flik et al. 2006), but these 2 receptors are thought to have different roles (Dautzenberg et al. 2001, Dautzenberg \& Hauger 2002, Bale \& Vale 2004). CRH-R1 regulates HPA/HPI responses to stress (Timpl et al. 1998) whereas, in mammals at least, CRH-R2 appears to fine tune longer-term changes in stress-coping behaviors (Dautzenberg et al. 2001). Given the proposed role for CRH-R2 receptor signaling in mammals, differences in CRH-R2 receptor expression in the brain of fish might associate with the expression of anxiety- and depression-like behaviors (Bale \& Vale 2004). In fish, this means that CRH-R2 pathways might mediate diverse behaviors including shelter use or aggression, which we indeed observed to be performed at higher rates in male bicolor damselfish inhabiting rubble areas of the coral reef. It is important to note, however, that little is known about the functional differences between CRH-R1 and CRH-R2 signaling pathways in teleost fishes, and additional studies are needed to understand the role these receptors play in HPI reactivity and stress-coping behaviors in fish.

\section{Ecological significance of habitat-associated variation in stress-response systems}

Taken as a whole, the behavioral, physiological and ecological data provided here and in previous work by Schrandt et al. (2011) suggest that intraspecific behavioral variation of bicolor damselfish on Curaçao's leeward fringing coral reef may be attributed to the influences of local ecological conditions on stress-response pathways. Stress pathways such as the HPI axis evolved to mediate interactions between the environment, physiology and behavior in patterns that ultimately affect an individual's fitness (Ricklefs \& Wikelski 2002, Wingfield et al. 2008), and studying endocrine mechanisms in an ecologi- cally relevant context can provide new insights into how ecological conditions shape patterns of intraspecific behavioral variation to fit the local environment. Although rarely studied in a field context, environmental influences on endocrine pathways are common and have been documented previously in wild fishes. For example, social conditions such as conspecific density and the occurrence of territorial intrusions impact HPG axis signaling, with implications for reproductive function (Pankhurst \& Barnett 1993, Pankhurst \& Van Der Kraak 1997). Similarly, neuroendocrine pathways such as the vasotocin system, which mediates osmotic balance and regulates sociosexual behaviors, respond to both physical and social conditions (Godwin et al. 2000, Lema 2006). And, as with other endocrine signaling pathways, stressful stimuli experienced during early life can alter HPA/HPI function so that these pathways become hyper-responsive, which can subsequently lead to enhanced fearful behaviors and anxiety or more intense or prolonged physiological responses to acute stressors (Meaney 2001, Ellis et al. 2006).

But what broader implications might such habitatassociated spatial patterns of intraspecific variation in stress physiology hold for bicolor damselfish? Captive-reared rainbow trout Oncorhynchus mykiss that were artificially selected to have either high or low post-stress plasma cortisol responses also differed in their behavioral responses to novel environments (Ruiz-Gomez et al. 2011). This observation suggests that individual differences in stress-coping styles may impact how those individuals respond to environmental change. Given the habitat-associated differences in HPI stress reactivity observed here with wild bicolor damselfish, those findings may mean that damselfish from different habitats might have divergent capacities for responding to changes in either coral reef environment. It is also important to note that several recent studies have found evidence that coral reef fishes can exhibit habitat-associated intraspecific variation in life history traits (e.g. growth rate) and reproductive condition (Afonso et al. 2008, Pankhurst et al. 2008, Feary et al. 2009, Paddack et al. 2009). For instance, Feary et al. (2009) found that 2 tropical damselfish species, Chrysiptera parasema and Dascyllus melanurus, showed lower growth rates in disturbed habitats with more dead corals than in areas with abundant live coral cover. Given previously established relationships between stress physiology and other traits such as growth and reproductive function in fishes (e.g. Pankhurst 2001; reviewed by Wendelaar Bonga 1997, Mommsen et al. 1999) - and our findings here with bicolor dam- 
selfish - it is possible that spatial variation in behavioral, reproductive or life history traits in other marine fishes might be attributed in part to ecologically linked variation in stress-coping styles.

There is also recent evidence from damselfishes on the Great Barrier Reef that exposure to more frequent aggressive interactions may have significant effects on offspring fitness-including the embryo development and larval body size - by altering circulating levels of cortisol (McCormick 2006, 2009). Gagliano \& McCormick (2009) found that experimentally increasing cortisol levels in the eggs of the damselfish Pomacentrus amboinensis led to increased egg mortality and delayed hatching. This intriguing finding implies that any habitat-associated changes in stress physiology might lead to multigenerational effects through maternal effects of stress hormones on offspring. In several studies with terrestrial vertebrates, increased levels of stress indicators have been associated with sub-optimal or degraded habitats (reviewed by Busch \& Hayward 2009). Any natural or anthropogenic stressor that affects the dynamics of behavioral interactions, or some other ecological demand that affects physiological stress status of reproductively active adult fish, could therefore result in the multigenerational effects on fitness, and broader impacts on fish populations.

\section{CONCLUSIONS}

The results presented here provide evidence that bicolor damselfish from 2 physically distinct coral reef habitats, rubble and reef, show differences in how several key stress-associated gene transcripts in the brain respond to acute stress. Bicolor damselfish in the rubble and reef habitats differed significantly in behavior (see also Schrandt et al. 2011), and our findings of differences in stress reactivity provide a physiological link between the ecological conditions of these habitats and habitat-associated variation in damselfish behavior. The variation in physiological stress responses is particularly notable because it occurred over very small spatial scales ( $35 \mathrm{~m}$ distance) on the coral reef, and also appeared to vary between the sexes. Taken as a whole, these findings suggest that local variation in coral reef characteristics can generate physiological differences in how fish respond to stressors, and illustrate how studies of the behavior and stress physiology of marine organisms in an ecologically relevant context can provide novel insights into how animals are affected by their local habitat conditions.
Acknowledgements. This research was funded by a Pilot Project award from the Center for Marine Science, University of North Carolina Wilmington, to S.C.L. and a Sigma Xi Grant-in-Aid of Research to M.N.S. The authors thank Dr Kristin Hardy, Kaitlin Johnson, Ocean Encounters West, Matthew Birk, Amy Metheny, Dr Steve McCormick and Amy Regish for methodological assistance. All research was carried out following guidelines of the Animal Care and Use Committee of UNC Wilmington. The authors also thank Drs Christopher Finelli, John Godwin and Fred Scharf for comments that greatly improved this manuscript.

\section{LITERATURE CITED}

Afonso P, Morato T, Santos RS (2008) Spatial patterns in reproductive traits of the temperate parrotfish Sparisoma cretense. Fish Res 90:92-99

Alderman SL, Raine JC, Bernier NJ (2008) Distribution and regional stressor-induced regulation of corticotropinreleasing factor binding protein in rainbow trout (Oncorhynchus mykiss). J Comp Neurol 20:347-358

Arai M, Assil IQ, Abou-Samra AB (2001) Characterization of three corticotropin-releasing factor receptors in catfish: a novel third receptor is predominantly expressed in pituitary and urophysis. Endocrinology 142:446-454

Bale TL, Vale WW (2004) CRH and CRH receptors: role in stress responsiveness and other behaviors. Annu Rev Pharmacol Toxicol 44:525-557

> Barton BA (2002) Stress in fish: a diversity of responses with particular reference to changes in circulating corticosteroids. Integr Comp Biol 42:517-525

$>$ Bernier NJ, Craig PM (2005) CRH-related peptides contribute to stress response and regulation of appetite in hypoxic rainbow trout. Am J Physiol Regul Integr Comp Physiol 289:R982-R990

> Bernier NJ, Peter RE (2001) Appetite-suppressing effects of Urotensin I and corticotropin-releasing hormone in goldfish (Carassius auratus). Neuroendocrinology 73: 248-260

Bernier NJ, Lin X, Peter RE (1999) Differential expression of corticotrophin-releasing factor $(\mathrm{CRH})$ and urotensin 1 precursor genes, and evidence of CRH gene expression regulated by cortisol in goldfish brain. Gen Comp Endocrinol 116:461-477

Bernier NJ, Alderman SL, Bristow EN (2008) Heads or tails? Stressor-specific expression of corticotropin-releasing factor and urotensin 1 in the preoptic area and caudal neurosecretory system of rainbow trout. J Endocrinol 196:637-648

Boinski S (1999) Geographic variation in behavior of a primate taxon: stress response as a proximate mechanism in the evolution of social behavior. In: Foster SA, Endler JA (eds) Geographic variation in behavior: perspectives on evolutionary mechanisms. Oxford University Press, New York, NY, p 95-120

Busch DS, Hayward LS (2009) Stress in a conservation context: a discussion of gluccocorticoid actions and how levels change with conservation-relevant variables. Biol Conserv 142:2844-2853

> Carey JB, McCormick SD (1998) Atlantic salmon smolts are more responsive to an acute handling and confinement stress than parr. Aquaculture 168:237-253

Clements S, Schreck CB, Larsen DA, Dickhoff WW (2002) Central administration of corticotropin-releasing hor- 
mone stimulates locomotor activity in juvenile Chinook salmon (Oncorhynchus tshawytscha). Gen Comp Endocrinol 125:319-327

> Cockrem JF (2007) Stress, corticosterone responses and avian personalities. J Ornithol 148(Suppl 2):169-178

Dautzenberg FM, Hauger RL (2002) The CRH peptide family and their receptors: yet more partners discovered. Trends Pharmacol Sci 23:71-77

> Dautzenberg FM, Kilpatrick GJ, Hauger RL, Moreau JL (2001) Molecular biology of the CRH receptors - in the mood. Peptides 22:753-760

> Denver RJ (2009) Structural and functional evolution of vertebrate neuroendocrine stress systems. Ann NY Acad Sci 1163:1-16

> DeRaedemaecker F, Miliou A, Perkins R (2010) Fish community structure on littoral rocky shores in the Eastern Aegean Sea: effects of exposure and substratum. Estuar Coast Shelf Sci 90:35-44

Ellis BJ, Jackson JJ, Boyce WT (2006) The stress response system: universality and adaptive individual differences. Dev Rev 26:175-212

Feary DA, McCormick MI, Jones GP (2009) Growth of reef fishes in response to live coral cover. J Exp Mar Biol Ecol 373:45-49

> Flik G, Klaren PHM, van den Burg EH, Metz JR, Huising MO (2006) CRH and stress in fish. Gen Comp Endocrinol 146:36-44

> Gagliano M, McCormick MI (2009) Hormonally mediated maternal effects shape offspring survival potential in stressful environments. Oecologia 160:657-665

> Godwin J, Sawby R, Warner RR, Crews D (2000) Hypothalamic arginine vasotocin mRNA abundance variation across sexes and with sex change in a coral reef fish. Brain Behav Evol 55:77-84

> Grammatopoulos DK, Chrousos GP (2002) Functional characteristics of $\mathrm{CRH}$ receptors and potential clinical applications of CRH-receptor antagonists. Trends Endocrinol Metab 13:436-444

Harborne AR, Mumby PJ, Kappel CV, Dahlgren CP, Micheli F, Holmes KE, Brumbaugh DR (2008) Tropical coastal habitats as surrogates of fish community structure, grazing, and fisheries value. Ecol Appl 18:1689-1701

> Huising MO, Metz JR, van Schooten C, Taverne-Thiele AJ, Hermsen T, Verburg-van Kemenade BML, Flik G (2004) Structural characterization of a cyprinid (Cyprinus carpio L.) CRH, CRH-BP and CRH-R1, and the role of these proteins in the acute stress response. J Mol Endocrinol 32: $627-648$

Kavanagh KD, Olney JE (2006) Ecological correlates of population density and behavior in the circumtropical black triggerfish Melichthys niger (Balistidae). Environ Biol Fishes 76:387-398

Kohler KE, Gill SM (2006) Coral Point Count with Excel extensions (CPCe): a Visual Basic program for the determination of coral and substrate coverage using random point count methodology. Comp Geosci 32:1259-1269

> Lema SC (2006) Population divergence in plasticity of the AVT system and its association with aggressive behaviors in a Death Valley pupfish. Horm Behav 50:183-193

> Lowry CA, Moore FL (2006) Regulation of behavioral responses by corticotropin-releasing factor. Gen Comp Endocrinol 146:19-27

> Lucas JR, Freeberg TM, Egbert J, Schwabl H (2006) Fecal corticosterone, body mass, and caching rates of Carolina chickadees (Poecile carolinensis) from disturbed and undisturbed sites. Horm Behav 49:634-643

Luckhurst BE, Luckhurst K (1978) Analysis of the influence of substrate variables on coral reef fish communities. Mar Biol 49:317-323

> McCormick MI (2006) Mothers matter: crowding leads to stressed mothers and smaller offspring in marine fish. Ecology 87:1104-1109

- McCormick MI (2009) Indirect effects of heterospecific interactions on progeny size through maternal stress. Oikos 118:744-752

Meaney MJ (2001) Maternal care, gene expression, and the transmission of individual differences in stress reactivity across generations. Annu Rev Neurosci 24:1161-1192

Metz JR, Huising MO, Meek J, Taverne-Thiele AJ, Wendelaar-Bonga SE, Flik G (2004) Localisation, expression and control of adrenocorticotropic hormone in the nucleus preopticus and pituitary gland of common carp (Cyprinus carpio L.). J Endocrinol 182:23-31

Mommsen TP, Vijayan MM, Moon TW (1999) Cortisol in teleosts: dynamics, mechanisms of action, and metabolic regulation. Rev Fish Biol Fish 9:211-268

Müllner A, Linsenmair KE, Wikelski M (2004) Exposure to ecotourism reduces survival and affects stress response in hoatzin chicks (Opisthocomus hoazin). Biol Conserv 118:549-558

Mumby PJ, Wabnitz CCC (2002) Spatial patterns of aggression, territory size, and harem size in five sympatric Caribbean parrotfish species. Environ Biol Fishes 63: 265-279

Myrberg AA Jr (1972) Ethology of the bicolor damselfish Eupomacentrus partitus (Pisces: Pomacentridae): a comparative analysis of laboratory and field behavior. Anim Behav Monogr 5:197-283

Øverli Ø, Sørensen C, Pulman KGT, Pottiner TG, Korzan W, Summers CH, Nilsson GE (2007) Evolutionary background for stress coping styles: relationships between physiological, behavioral, and cognitive traits in nonmammalian vertebrates. Neurosci Biobehav Rev 31: 396-412

Paddack MJ, Sponaugle S, Cowen RK (2009) Small-scale demographic variation in the stoplight parrotfish Sparisoma viride. J Fish Biol 75:2509-2526

Pankhurst NW (2001) Stress inhibition of reproductive endocrine processes in a natural population of the spiny damselfish Acanthochromis polyacanthus. Mar Freshw Res 52:753-761

> Pankhurst NW (2011) The endocrinology of stress in fish: an environmental perspective. Gen Comp Endocrinol 170: 265-275

Pankhurst NW, Barnett CW (1993) Relationship of population density, territorial interaction and plasma levels of gonadal steroids in spawning male demoiselles Chromis dispilus (Pisces: Pomacentridae). Gen Comp Endocrinol 90:168-176

Pankhurst NW, Van Der Kraak G (1997) Effects of stress on reproduction and growth of fish. In: Iwama GK, Sumpter J, Pickering AD, Schreck CB (eds) Fish stress and health in aquaculture. Cambridge University Press, Cambridge, p 73-93

Pankhurst NW, Fitzgibbon QP, Pankhurst PM, King HR (2008) Habitat-related variation in reproductive endocrine condition in the coral reef damselfish Acanthochromis polyacanthus. Gen Comp Endocrinol 155: 386-397

Pittman QJ, Hollenerg MD (2009) Urotensin 1-CRH- 
Urocortins: a mermaid's tail. Gen Comp Endocrinol 164: 7-14

Potter E, Behan DP, Fischer WH, Linton EA, Lowry PJ, Vale WW (1991) Cloning and characterization of the cDNAs for human and rat corticotropin releasing factor-binding proteins. Nature 349:423-426

Ramsay JM, Feist GW, Varga ZM, Westerfield M, Kent ML, Schreck CB (2006) Whole-body cortisol is an indicator of crowding stress in adult zebrafish, Danio rerio. Aquaculture 258:565-574

Ricklefs R, Wikelski M (2002) The physiology/life history nexus. Trends Ecol Evol 17:462-468

Roberts CM, Ormond RFG (1987) Habitat complexity and coral reef fish diversity and abundance on Red Sea fringing reefs. Mar Ecol Prog Ser 41:1-8

Ruiz-Gomez ML, Huntingford FA, Øverli Ø, Thömqvist PO, Höglund E (2011) Response to environmental change in rainbow trout selected for divergent stress coping styles. Physiol Behav 102:317-322

Schrandt MN, Johnson KM, Hardy KM, Lema SC (2011) Physical and social habitat conditions across a coral reef shape spatial patterns of intraspecific behavioral variation in a demersal reef fish. PSZN I: Mar Ecol (in press) doi:10.1111/j.1439-0485.2011.00475.x

Seasholtz AF, Valverde RA, Denver RJ (2002) Corticotropin releasing hormone-binding protein: biochemistry and

Editorial responsibility: Nicholas Tolimieri,

Seattle, Washington, USA function from fishes to mammals. J Endocrinol 175:89-97

Silva PIM, Martins CIM, Engrola S, Marino G, Øverli Ø, Conceicao LEC (2010) Individual differences in cortisol levels and behaviour of Senegalese sole (Solea senegalensis) juveniles: evidence for coping styles. Appl Anim Behav Sci 124:75-81

Snekser JL, Leese J, Ganim A, Itzkowitz M (2009) Caribbean damselfish with varying territory quality: correlated behaviors but not a syndrome. Behav Ecol 20: $124-130$

Timpl P, Spanagel R, Sillaber I, Kresse A and others (1998) Impaired stress response and reduced anxiety in mice lacking a functional corticotropin-releasing hormone receptor 1. Nat Genet 19:162-166

> Wasser SK, Bevis K, King G, Hanson E (1997) Noninvasive physiological measures of disturbance in the northern spotted owl. Conserv Biol 11:1019-1022

- Wendelaar Bonga SE (1997) The stress response in fish. Physiol Rev 77:591-625

Wingfield JC, Visser ME, Williams TD (2008) Introduction. Integration of ecology and endocrinology in avian reproduction: a new synthesis. Philos Trans R Soc Lond B Biol Sci 363:1581-1588

Yao M, Denver RJ (2007) Regulation of vertebrate corticotropin-releasing factor genes. Gen Comp Endocrinol 153:200-216

Submitted: February 18, 2011; Accepted: September 21, 2011 Proofs received from author(s): December 6, 2011 